\author{
Janusz Kaczmarek \\ Katedra Logiki i Metodologii Nauk \\ Uniwersytet Łódzki \\ kaczmarek@filozof.uni.lodz.pl
}

\title{
RETORYKA W NAUCE?
}

\begin{abstract}
ABSTRAKT
Sądzić można, że umiejętności retoryczne stosowane są przede wszystkim w życiu społecznym, kulturowym czy w polityce, ale są nieobecne lub zbyteczne w nauce, w szczególności w naukach o subtelnych metodach badawczych. Na przykładzie ekonomii, filozofii, psychologii i socjologii próbuję wykazać, że argumentacja retoryczna - co nie musi kojarzyć się z argumentacją błędną - jest obecna w tych naukach. To zaś oznacza, że nie tylko kwestia logosu, ale także patosu i etosu jest znaczącym elementem badań naukowych i argumentacji przeprowadzanych w nauce.
\end{abstract}

\section{SŁOWA KLUCZOWE}

Retoryka, argumentacja, argumentacja w nauce, ethos, pathos, logos.

\section{WSTĘP}

Retorykę możemy określić - w najogólniejszym sensie - jako umiejętność przekonywania do ustalonych twierdzeń bądź przekonań, sądów czy racji ${ }^{1}$. Retoryka dotyczy zatem szerokiej dziedziny działań człowieka: działań w obszarze nauki, kultury, polityki czy życia codziennego - życia w społeczeństwie, $w$ rodzinie, w relacjach $\mathrm{z}$ drugim człowiekiem. Czasem podkreśla się, że jeden z twórców retoryki, Arystoteles, zwracał uwagę na odróżnienie nauki od opinii. Nauka ma za przedmiot to, co konieczne, niezmienne

\footnotetext{
${ }^{1}$ W pracy pod redakcją M. Barłowskiej Retoryka, Piotr Wilczek zauważa we wstępie: „Według klasycznej definicji retoryka to ars bene dicendi - sztuka dobrego mówienia, gdzie ars oznaczało bardziej umiejętność techniczną, niż sztukę w dzisiejszym rozumieniu, bene wiązało się z pięknem estetycznym, ale też z dobrem jako wartością etyczną, wreszcie dicendi dotyczyło zarówno tekstów mówionych jak i pisanych" [Bartłowska i inni 2008, s. 8].
} 
i ogólne, podczas gdy opinia opiera się na tym, co niekonieczne, zmienne i konkretne ${ }^{2}$. Stąd nauka nie musi odwoływać się do perswazji, a zatem nie wykorzystuje retoryki, natomiast w sferze opinii odwołujemy się do retoryki, ta zaś do ethosu, pathosu i logosu. Te trzy elementy wskazuje w swej Retoryce Arystoteles charakteryzując je następująco:

Środki przekonywania uzyskane za pośrednictwem mowy dzielą się na trzy rodzaje. Jedne z nich zależą od charakteru mówcy, inne - od nastawienia, w jakie wprawia się słuchacza, inne jeszcze - od samej mowy ze względu na rzeczywiste lub pozorne dowodzenie [Arystoteles 1988, s. 67].

Mówiąc o trzech składowych retoryki, mamy na myśli po pierwsze: właściwe, często logiczne, uporządkowanie wypowiedzi (argumentów) przez mówiącego $(\log o s)^{3}$, po drugie: oddziaływanie mówiącego na słuchacza bądź słuchaczy i wywołanie odpowiedniej reakcji (pathos, np. przyjęcie argumentacji, podjęcie przez słuchacza określonych działań, zachowań, postaw) oraz po trzecie: cnoty i wartości reprezentowane przez samego mówcę (ethos), kto bowiem posiada autorytet bądź wypowiada się jako ekspert w danym temacie, ten łatwiej przekonuje do swego stanowiska ${ }^{4}$.

\section{PROBLEM}

Postawmy zatem pytanie: czy rzeczywiście owe trzy składowe retoryki są zbędne w nauce? Pytanie to można pogłębić stawiając problem: czy w różnych naukach (formalnych, przyrodniczych, społecznych, humanistycznych) w tym samym stopniu zauważamy zbędność (o ile w ogóle) retoryki? Zanim podamy odpowiedź, wyjdźmy od prostych przykładów wypowiedzi (argumentacji i dyskusji) toczonych przez ludzi.

\footnotetext{
${ }^{2}$ Por. hasło retoryka w Powszechnej Encyklopedii Filozofii, t. 8, (2008), dostępne także w wersji elektronicznej.

${ }^{3}$ Mówiąc o logosie niektórzy akcentują ważność samego języka, umiejętność wypowiadania się, czy stosowaną perswazję. Sądzę, że ważniejsze - w szczególności w rzetelnej argumentacji - są aspekty metodologiczne: jasność pojęć i twierdzeń, stosowane typy wnioskowań, czytelność przekazu itp. Oczywiście spotykamy różne typy argumentów i różne odmiany argumentacji - od dedukcyjnych po indukcyjne, a nawet takie, dla których trudno znaleźć sensowny schemat [por. [Szymanek 2001, s. 37-45 (hasło: ARGUMENT) oraz Tokarz 2006, str. 123-154 (wykład 5: Sztuka argumentacji)].

${ }^{4}$ Arystoteles podkreślał m.in., że jesteśmy skłonni wierzyć tym, którzy są uczciwi, wiarygodni.
} 


\section{PRZYKŁADY ARGUMENTACJI RETORYCZNEJ}

Przykład 1. Dyskusja pomiędzy radnymi gminy X:

Przewodniczący: Panie i Panowie, musimy rozwiązać problem zbyt dużego obciążenia naszego parkingu przed Urzędem Gminy.

Radny 1: Przecież płacą za parking, zatem im więcej klientów, tym lepiej.

Przewodniczący: Tak, ale co się dzieje wokół parkingu? Przecież blokują już nawet miejsca przed przedszkolem i Domem Kultury. Bałagan, bałagan, (...). Trzeba zredukować obciążenie parkingu przynajmniej o jedną piątą.

Radny 2: Proponuję podnieść cenę za parking o 15\% (śmiech wśród pozostałych radnych).

Radny 3: Drogi kolego, a co to za zależność? $15 \%$ to raptem 45 groszy za godzinę. Sądzi Pan, że to załatwi sprawę? Chcą parkować, to parkują! A Pan tu z jakimiś procentami wyjeżdża! (śmiech wśród pozostałych radnych). Niech Pan pomyśli o rozsądnym dla nas rozwiązaniu (śmiech trwa nadal).

Przykład 2. Fragment dialogu z filmu Piękny umyst:

John Nash: Czy to, co nas łączy, gwarantuje stały związek? Potrzebuję dowodu, potwierdzalnych danych. Danych.

Alicja Nash: Przepraszam, daj mi chwilę... muszę przedefiniować moje dziewczęce, romantyczne wyobrażenia. Dowód, potwierdzalne dane? Dobrze. Jak wielki jest wszechświat?

John Nash: Nieskończenie.

Alicja Nash: Skąd wiesz?

John Nash: Bo wskazują na to wszystkie dane.

Alicja Nash: Ale jeszcze tego nie dowiedziono? Nie widziałeś całego wszechświata. Skąd możesz wiedzieć?

John Nash: Nie wiem, wierzę w to.

Alicja Nash: Podobnie jest z miłością. Tylko że nie wiesz, ... czy ja chcę wyjść za ciebie.

Przykład 3. Rozmowa dwóch hydraulików (mistrza i ucznia):

Mistrz: No, jutro robotę dokończymy, a po jutrze święto.

Uczeń: A, ... 15 sierpnia, tzw. cud nad Wisłą.

Mistrz: A tak, cud nad Wisłą. Matka Boska ukazała się Polakom i Ruskim. Ale Ruscy tak się wystraszyli, że pognali spod Warszawy na wschód.

Uczeń: Szefie, no jak to? Ukazała się Matka Boska? Chyba to jakaś halucynacja!

Mistrz: Oj, młody. Halucynacje to można mieć, gdy się za dużo wypije! Dorośniesz, to zrozumiesz, co to cud, co to znak czasu! 
W tych trzech przykładach spotykamy się z próbą argumentacji pewnych tez. W przykładzie pierwszym Radny 2 stawia tezę, że odciążenie parkingu będzie rezultatem zwiększenia opłaty. Robi to jednak bez dodatkowych wyjaśnień i wzbudza uśmiech wśród pozostałych radnych, którzy nie widzą tu żadnego związku między obłożeniem parkingu a ceną za parkowanie. W przykładzie drugim powstaje problem tego, co istnieje a co nie, co jest pewne a co nie pewne. Czy dla miłości, związku, więzi, między ludźmi można wskazać dane - w domyśle: naukowe, empiryczne. John i Alicja zdają się być przekonani, że pewne kwestie wykraczają poza dane, pozostają kwestią wiary. W przykładzie trzecim hydraulik-mistrz próbuje swoim autorytetem (zawodowym, doświadczeniem życiowym) przekonać, że zdarzenie niezwykłe miało miejsce. Młody hydraulik, uczeń, nie ma jeszcze - prawdopodobnie - takiego życiowego doświadczenia, by zrozumieć niezwykłe znaki czasu. To, co niezwykłe postrzega jako fantazję ludzi (żołnierzy, ale też hydraulika-mistrza).

W każdym przykładzie możemy zauważyć - w większym lub mniejszym stopniu - obecność składowych: logosu, ethosu, pathosu. Alicja daje sobie czas do namysłu, by przekonać Johna (Przepraszam, daj mi chwilę... muszę przedefiniować moje dziewczęce, romantyczne wyobrażenia) i podaje stosowną argumentację (logos). Radny 3 wykorzystuje atmosferę wśród radnych (pathos) i podkreśla brak związku między obciążeniem parkingu a ceną za parkowanie (Drogi kolego, a co to za zależność? 15\% to raptem 45 groszy za godzinę), co więcej, podgrzewa stosunek radnych do Radnego 2 (Niech Pan pomyśli o rozsądnym dla nas rozwiązaniu). Hydraulik-mistrz z racji swego wieku i autorytetu zawodowego (ethos) podkreśla jeszcze znaczenie swych argumentów (Dorośniesz, to zrozumiesz ...). Oczywiście tych elementów można tu wskazać więcej.

\section{PRZYKŁADY ARGUMENTACJI W NAUCE}

A jak to jest w nauce? Czy Arystoteles miał rację, mówiąc że retoryka jest w nauce zbędna? Stosownie do powyższych przykładów rozważmy teraz trzy fragmenty prac naukowych odnoszących się - mniej lub więcej - do tez, które rozważane były w przykładach 1, 2 i 3. Wybieramy fragmenty z ekonomii, filozofii i socjologii. Oto one:

Fragment z Ekonomii Davide'a Begg'a [Begg, Fisher i Dornbush 1993], współczesnego wybitnego brytyjskiego ekonomisty urodzonego w roku 1950: 
Wychodzimy od problemu cenowej elastyczności popytu:

Cenowa elastyczność popytu to stosunek względnej zmiany wielkości popytu na dane dobro do względnej zmiany jego ceny [tamże, s. 112].

\section{I dalej:}

Załóżmy, że elastyczność popytu na korzystanie z płatnych parkingów miejskich wynosi $-1,5$. Przy innych czynnikach nie zmienionych, wzrost opłat parkingowych o $1 \%$ spowoduje spadek popytu o $1,5 \%$. Przy obecnej stawce, wynoszącej $£ 1$ za godzinę, występuje niedobór powierzchni parkingowej oceniany na $15 \%$. Przed parkingami ustawiają się kolejki samochodów, a na ulicach tworzą się korki. O ile należałoby podnieść wysokość opłat za parkowanie, aby zlikwidować kolejki oczekujących?

Skoro elastyczność popytu wynosi $-1,5$, to podniesienie opłat parkingowych o $10 \%$ zmniejszy popyt o $15 \%$, eliminując kolejki. Niektórzy przesiądą się do autobusów, inni zostawią swe samochody poza centrum handlowym i pójdą dalej pieszo, jeszcze inni zaczną dojeżdżać do miasta razem z sąsiadami czy kolegami z pracy. Elastyczność popytu odzwierciedla te i inne możliwości substytucji, ograniczającej potrzebę korzystania z parkingów miejskich. Gdyby możliwości te były mniejsze, to nie jest wykluczone, że elastyczność popytu wyniosłaby tylko $-0,5$. Wówczas rozładowanie tłoku na parkingu wymagałoby podniesienia opłat o $30 \%$ [tamże, s. 116-168].

\section{Fragment z Traktatu George'a Berkeleya (1685-1753, irlandzkiego filozofa, duchownego i misjonarza anglikańskiego):}

Każdy przyzna, że ani nasze myśli, ani uczucia, ani idee ukształtowane przez wyobraźnię nie istnieją poza umysłem. Otóż wydaje się nie mniej oczywiste, że różne wrażenia zmysłowe, to znaczy idee wyryte na zmysłach, jakkolwiek byłyby zmieszane i połączone ze sobą (to znaczy bez względu na to, na jakie składałyby się przedmioty), nie mogą istnieć inaczej, jak tylko w umyśle, który je postrzega. Myślę, że każdy może się o tym przekonać naocznie, kto tylko zważy, co się rozumie przez termin istnieć, wówczas gdy stosuje się on do rzeczy zmysłowych. Mówię, że stół, na którym piszę, istnieje; znaczy to, że go widzę i odczuwam dotykiem; jeślibym zaś był poza swoją pracownią, powiedziałbym, że istniał - rozumiejąc przez to, że gdybym się w swej pracowni znajdował, mógłbym go postrzegać; lub że jakiś inny duch teraz go postrzega. Był tu zapach, to znaczy, że go odczuto węchem; był dźwięk, to znaczy, że go słyszano; była barwa czy kształt, a więc spostrzeżono je wzrokiem lub dotykiem. To jest wszystko, co mogę rozumieć przez te i tym podobne wyrażenia. Bo to, co się mówi o absolutnym istnieniu rzeczy niemyślących, bez żadnego związku z tym, że są postrzegane, wydaje mi się całkowicie niezrozumiałe. Ich esse [istnienie] to percipi [bycie postrzeganym] - i nie jest możliwe, aby miały jakiekolwiek istnienie poza umysłami, czyli rzeczami myślącymi, które je postrzegają [Berkeley 1956, s. 3]. 
Fragment z pracy Uczucia i moralność tłumu Gustave'a Le Bona (1841-1931, francuskiego socjologa i psychologa, twórcy psychologii tłumu):

Podając główne cechy tłumu, podkreśliłem to, że jedną z nich jest nadzwyczajna zdolność do ulegania sugestii; wskazałem też na to, że jest ona zaraźliwa w każdej ludzkiej zbiorowości. To nam tłumaczy nadzwyczajną szybkość potęgowania się uczuć tłumu w pewnym oznaczonym kierunku (...).

Tak wygląda ów mechanizm często powtarzających się w dziejach, zbiorowych halucynacji, które posiadają wszystkie cechy wiarygodności, albowiem potwierdzają ich istnienie tysiące osób. Powyższej zasady nie może osłabić uwaga, że jednostki tworzące tłum posiadają rozmaitą zdolność umysłu, nie ma to bowiem najmniejszego znaczenia w thumie, gdyż zarówno nieuk, jak i uczony, kiedy staje się cząstką tłumu, traci zdolność obiektywnej oceny faktów. Twierdzenie to może wydać się śmieszne. Na dowód jego prawdziwości musiałbym przytoczyć znaczną liczbę faktów historycznych, co w ramach niniejszej pracy nie da się wykonać. Przytoczę tylko kilka przykładów dowolnie wybranych z wielu innych, aby Czytelnik nie myślał, że to twierdzenia bez pokrycia.

Następujący przykład jest bardzo charakterystyczny, ponieważ należy do grupy zbiorowych halucynacji opanowujących thum, który składa się zarówno z nieuków, jak też z ludzi bardzo wykształconych. Podał go nam porucznik marynarki, Julian Félix, w swej pracy $O$ prądach morskich:

„Okręt La Belle-Poule krążył po morzu, szukając łodzi Le Berceau, która przepadła w czasie gwałtownej burzy. W jasny i słoneczny dzień z masztu dano znak, że na widnokręgu ukazała się jakaś łódź w niebezpieczeństwie. Oczy wszystkich zwracają się w stronę wskazanego punktu; cała załoga wraz z oficerami widzi na morzu tratwę wypełnioną ludźmi, holowana przez łodzie, na których powiewały sygnały alarmowe. Admirał Desfossés rozkazał spuścić szalupę na ratunek rozbitkom. Marynarze, zbliżając się do owej tratwy, dokładnie widzieli, ,jak wielu ludzi wyciągało do nich ręce, słyszeli głuchy i niewyraźny ich bełkot". Podpłynąwszy jednak do owej domniemanej tratwy, ujrzeli po prostu kilka gałęzi pokrytych liśćmi, które fale morskie porwały z pobliskiego brzegu. I wtedy dopiero, pod wpływem tak namacalnej rzeczywistości, prysnęła halucynacja."

Przykład ten dostatecznie objaśnia nam ów mechanizm zbiorowych halucynacji, o którym mówiliśmy powyżej. $Z$ jednej strony thum w stanie wyczekiwania, $\mathrm{z}$ drugiej znowu sugestia wywołana przez znak dany z masztu, iż na pełnym morzu znajduje się statek w niebezpieczeństwie. Potrafiła ona w zaraźliwy sposób opanować nie tylko marynarzy, ale i oficerów [Le Bon 2007(1895), s. 182-183].

Spróbujmy przeanalizować powyższe teksty - dwa naukowe i jeden filozoficzny - z punktu widzenia obecności logosu, ethosu i pathosu.

$L O G O S$. W każdym z przytoczonych fragmentów występuje to, co rozumiane jest w retoryce pod nazwą logosu. Nie da się ukryć, że rzetelny, czasem nawet wyrafinowany, sposób argumentacji na rzecz głównej tezy, jest w tych 
tekstach obecny. Begg pokazuje, w jaki sposób od pojęcia cenowej elastyczności popytu przejść do rozważenia konkretnego problemu: zależności między niedoborem powierzchni parkingowej a ceną za parking. Pojęcie cenowej elastyczności ma charakter teoretyczny, aprioryczny, ale zależność między powierzchnią a ceną jest ustalana empirycznie poprzez analizę danych: jak wzrost bądź obniżka ceny wpływają na wykorzystanie parkingu (Begg podaje przy tym stosowne dane dotyczące popytu na dane dobro w zależności od ceny danego dobra). $Z$ kolei Berkeley przekonuje nas, że jedynym sensownym sposobem mówienia o istnieniu pewnych rzeczy, jest ten rodzaj istnienia, który potwierdzić możemy (aktualnie bądź potencjalnie) naszymi zmysłami (zapach odczuto węchem, dźwięk został usłyszany, barwa spostrzeżona), krótko: istnieć to być postrzeganym. Wszelkie inne sposoby istnienia - jak argumentuje - są wysoce niedorzeczne (np. tzw. istnienie absolutne, bez związku z tym, że odpowiednie rzeczy są postrzegane).

Fragment $z$ Le Bona to przykład argumentacji - podobnie jak w przypadku Begga - w ramach nauki społecznej. Le Bon uzasadnia tezę: tłum, niezależnie od osób, które go tworzą (uczeni - nieuki, mądrzy - głupi), podlega zbiorowym halucynacjom. Wywód Le Bona odwołuje do konkretnych przykładów, które - jak zaznacza autor - mogłyby być przytoczone w większej ilości (indukcja?). Co więcej, autor odwołuje się nie tylko do swoich spostrzeżeń, ale też do relacji naocznych świadków (odwołanie do pracy Félixa). I jak tu zatem nie zgodzić się z narracją autora?

ETHOS. Za każdym z tekstów „stoją” wybitni, a co najmniej bardzo znani, myśliciele. Twórca psychologii thumu, socjolog i psycholog, którego Psychologia tłumu jest wznawiana po dziś dzień; świetny ekonomista (doradca ważnych gremiów ekonomicznych, ale też autor bardzo rozpoznawalnego podręcznika: dwutomowej Ekonomii) oraz nietuzinkowy filozof a przy tym duchowny anglikański ${ }^{5}$. Za Arystotelesem możemy zatem powiedzieć, że postaci będące autorami powyższych fragmentów wzbudzają zaufanie, są autorytetami. Składowa ethos jest tu zatem obecna. Młodemu hydraulikowi nie musimy wierzyć w tezę o zbiorowej halucynacji, ale Le Bonowi jesteśmy skłonni - dowody są oczywiste, a może być ich więcej. I dochodzi autorytet!

PATHOS. Zastanówmy się teraz, w jaki sposób i jak mocno wpływają na nas argumenty zaproponowanych myślicieli? Czy pathos jest obecny w tych tekstach? Oczywiście pathos jest składnikiem, który odkryć możemy

\footnotetext{
${ }^{5}$ Berkeley opublikował swój Traktat w wieku 25 lat, jeszcze przed święceniami. Któż jednak pamięta o tym. Czytamy go jako filozofa i duchownego, tym bardziej, że nigdy swych poglądów się nie wyrzekł.
} 
w słuchaczach, ale ... który jest zamierzony w tekście (tu: w tekście naukowym). Pathos łatwiej jest wykryć w bezpośredniej argumentacji, gdy mówca i słuchacz znajdują się w interakcji bezpośredniej. Taką interakcję zauważamy choćby w dyskusji między radnymi. Tekst naukowy (filozoficzny) natomiast oddziałuje na czytelnika i następców (często w dużym odstępie czasu), którzy podejmują z autorem dyskusje. Żywa po dziś dzień dyskusja tezy Berkeleya czy problemów związanych z zachowaniami tłumu świadczyć może o wyraźnym wpływie idei naukowych na przyszłe idee i podejmowane badania, a to znaczy, że składowej pathosu nie możemy odrzucić, gdy rozważamy argumentację naukową. Jest też wysoce prawdopodobne, że gdyby Radny 2 odwoływał się do pojęć ekonomicznych, do teorii ekonomicznej oraz argumentował na podstawie danych empirycznych, zyskałby dla swego głosu większe uznanie.

\section{ODPOWIEDŹ}

Można przypuszczać, że logos, ethos i pathos są nieobecne (a co najmniej trzeciorzędne) w naukach formalnych - w matematyce i logice matematycznej. Tu rzeczywiście - jak wskazywał Arystoteles - zajmujemy się przedmiotami niezmiennymi, idealnymi, a jedynym typem argumentacji jest dedukcja. Nieistotne zatem stają się zarówno język i sposób narracji (składniki logosu) jak i autorytet naukowca (element ethosu). Warte jednak podkreślenia jest stanowisko wielu przedstawicieli pozostałych nauk, filozofii bądź kultury: matematyka, geometria, są przykładem wzorcowego myślenia, wzorcowego poznania, wzorcowego tworzenia teorii ${ }^{6}$. Choć więc Euklides nie miał być może na celu wpłynąć w pierwszym rzędzie na sposób prowadzenia badań $\mathrm{w}$ innych niż geometria dziedzinach, to jednak istotnie na te dziedziny wpłynął - przy tym, być może, nie samą treścią, ale sposobem przekazu treści. To wskazuje na obecność w naukach formalnych elementów klasycznie zaliczanych do retoryki.

Zauważmy też - dla przykładu na gruncie filozofii polskiej - że składnik ethosu i logosu obecny w wykładach, odczytach, seminariach i pracach Twardowskiego czy Ingardena zaowocował doniosłymi a czasem wybitnymi pracami z filozofii analitycznej i fenomenologicznej [por. Woleński 1985]7.

\footnotetext{
${ }^{6}$ Jest już dziś banałem przypominanie, że coraz więcej nauk wykorzystuje w swych badaniach narzędzia matematyczne. Już $\mathrm{w}$ starożytności zauważono, że reguły matematyczne rządzą również sztuką (kanony, proporcje, symetria), w tym muzyką (harmonia).

${ }^{7}$ Twardowski został m.in. tak scharakteryzowany: „Ale sprawą nie mniej ważną jest odtworzenie istotnych cech osobowości Twardowskiego, albowiem na oblicze założonej przez siebie szkoły wpłynął on nie tylko, a może nawet nie tyle swoimi poglądami, co właśnie charakterem i postawą" [Woleński 1985, s. 11].
} 
Natomiast doskonałym przykładem pathosu - potwierdzonym zresztą własnym sprawozdaniem - jest pointa Poppera o ,spotkaniu na ławce" w Volksgarten w Wiedniu z Tarskim, gdy ten ostatni objaśnił mu swoją definicję pojęcia prawdy: „Chociaż Tarski był tylko trochę starszy ode mnie i chociaż w tym czasie byliśmy sobie dość bliscy, patrzyłem na niego, jak na człowieka, którego naprawdę mogę uważać za nauczyciela fillozofii. Od nikogo nie nauczyłem się aż tak wiele" [por. Popper 1992, s. 411]. Wniosek może być zatem jeden: logos, ethos i pathos są nie tylko składnikami argumentacji retorycznej, lecz również - choć w różnym stopniu - naukowej i filozoficznej.

\section{BIBLIOGRAFIA}

Arystoteles, (1988), Retoryka - Poetyka, thum. H. Podbielski. Państwowe Wydawnictwo Naukowe.

Barłowska, M., Budzyńska-Daca, A., Wilczek, P. (red.), (2008), Retoryka. Wydawnictwo Naukowe PWN.

Begg, D., Fischer, S., Dornbush, R. (1984), Ekonomia. Państwowe Wydawnictwo Ekonomiczne.

Berkeley, G, (1956), Traktat o zasadach poznania ludzkiego. Państwowe Wydawnictwo Naukowe.

Le Bon, G. (1895), Uczucia i moralność tłumu, tłum. B. Paprocki, [w:] Sztompka i Kucia 2007, s. $181-189$.

Kochan, M. (red.) (2014), Sztuka debaty. Wydawnictwo Instytut Kultury Miejskiej i Słowo/Obraz Terytoria.

Popper, K. (1992), Wiedza obiektywna. Ewolucyjna teoria epistemologiczna, tłum. A. Chmielewski. Państwowe Wydawnictwo Naukowe.

Powszechna Encyklopedii Filozofii, t. 8, (2008). Wydawnictwo Katolickiego Uniwersytetu Lubelskiego i Towarzystwo św. Tomasza z Akwinu.

Sztompka, P, Kucia, M. (2007), Socjologia. Lektury. Wydawnictwo ZNAK.

Szymanek, K. (2001), Sztuka argumentacji. Stownik terminologiczny. Wydawnictwo Naukowe PWN.

Tokarz, M. (2006) Argumentacja. Perswazja. Manipulacja. Wyktady z teorii komunikacji. Gdańskie Wydawnictwo Psychologiczne.

Woleński, J. (1985), Filozoficzna szkoła lwowsko-warszawska. Państwowe Wydawnictwo Naukowe. 


\section{RHETORICS IN SCIENCE?}

(Abstract)

It seems that rhetorical skills are applied mostly in social, cultural or political life, but are absent or useless in science, particularly in sciences with subtle research methods. Considering just economics, philosophy and psychology I will try to demonstrate that rhetorical reasoning and justification, which need not be associated with defective argumentation, is an essential component of these sciences. It means that the matter of pathos and ethos and not only logos is an important element of research and scientific reasoning.

\section{KEYWORDS}

Rhetoric, argumentation, scientific reasoning, ethos, pathos, logos. 